\title{
PENGARUH KETERLIBATAN PEMANGKU KEPENTINGAN TERHADAP PENGUNGKAPAN LAPORAN KEBERLANJUTAN BERDASARKAN GLOBAL REPORTING INITIATIVE (GRI) G4
}

\author{
Fadhliatul Qisthi ${ }^{1}$, Meutia Fitri ${ }^{* 2}$ \\ ${ }^{1,2}$ Program Studi Akuntansi Fakultas Ekonomi Universitas Syiah Kuala \\ e-mail: fadhliatulqisthi@gmail.com ${ }^{1}$, meutia.fitri@unsyiah.ac.id ${ }^{* 2}$ \\ * Corresponding Author
}

\begin{abstract}
The purpose of this study is to determine whether there is any influence from the involvement of shareholders, employees, government, and media on the disclosure of sustainability reports based on GRI-G4. This study uses multiple regression linear methods with a quantitative causality study design supported by secondary data. Sample taken by the method of purposive sampling with the number of 35 companies listed in the Indonesia Stock Exchange in 2016-2019 and discovered140 sustainability report. The data collection technique used in this research is documentation. The results of this study indicate that companies that get shareholder involvement have a positive and significant effect on the disclosure of sustainability reports. It is suggested that shareholders react to the disclosure of sustainability reports which is pushed from the financial market so that the level of shareholder confidence increases by increasing the level of report disclosure. Meanwhile, the involvement of employees, government, and media has no effect on disclosure of sustainability report. This is because employees tend to think that social responsibility can add to the burden companies so that they can reduce their salarie, as well as weaknesses related to the regulations for disclosing sustainability reports and the media are platforms that are misused by people in Indonesia
\end{abstract}

Keywords: Stakeholder Engagement, Shareholders, Employees, Government, Media, Sustainability Report Disclosure

\section{Pendahuluan}

Saat ini perusahaan tidak hanya dituntut untuk mempertahankan profitabilitasnya, tetapi juga untuk mempertahankan bisnisnya secara berkelanjutan, yaitu dengan pembangunan dalam memenuhi kebutuhan dunia sekarang tanpa menolak kemampuan generasi masa mendatang (Simbolon dan Memed, 2016; Perrini, Russo, dan Tencati, 2006). Perusahaan yang hanya berorientasi pada profit dan mengabaikan perhatiannya pada aspek lingkungan dan sosial, tidak dapat menjamin kelangsungan usahanya di masa depan. Hal ini sudah sering terjadi di Indonesia terkait lemahnya perhatian perusahaan pada aspek sosial dan lingkungan (Rudyanto dan Siregar, 2018). Kasus yang pernah terjadi di Indonesia terkait aspek sosial, ekonomi dan lingkungan yaitu, kasus lumpur panas PT Lapindo Brantas yang terjadi pada tahun 2006, semburan lumpur panas yang meluap ke desa-desa hingga menenggelamkan wilayah kabupaten diakibatkan oleh pengeboran sumur gas yang mencemarkan lingkungan sekitar dan menimbulkan kerugian besar bagi masyarakat sekitar.

Cara menuju keberlanjutan adalah dengan melakukan pengungkapan laporan keberlanjutan (Rusdianto, 2013). Laporan keberlanjutan bagi perusahaan merupakan publikasi informasi yang mencerminkan kinerja organisasi dalam dimensi ekonomi, sosial, dan lingkungan yang dapat menjadi media bagi perusahaan untuk menginformasikan kinerja organisasi kepada seluruh pemangku kepentingan (stakeholders) (Freeman dan Mcvea, 2001). Pemangku kepentingan adalah individu, suatu kelompok, atau organisasi yang memiliki ketertarikan atau kepentingan dalam organisasi tertentu (Lamont, 2004). 
Di dalam penyusunan laporan keberlanjutan keterlibatan pemangku kepentingan menjadi sangat kritikal dengan harapan dan kebutuhan mereka pada titik acuan utama bagi banyak keputusan yang terlibat karena keterlibatan pemangku kepentingan dapat memfasilitasi pengidentifikasian dari isu-isu keberlanjutan dimana isu tersebut mencakup: isu-isu keperdulian, kebutuhan dan ekspektasi dari para pemangku kepentingan, maka dari itu beberapa pedoman (guideline) internasional seperti Global Reporting Initiative (GRI) dan Institute of Sosial and Ethical Accountability memposisikan keterlibatan pemangku kepentingan sebagai sarana utama untuk mengembangkan struktur laporan keberlanjutan (GRI, 2011; Owen, Hunt dan Swift, 2001).

Publikasi laporan keberlanjutan di Indonesia masih bersifat sukarela (voluntary) karena belum adanya standar khusus yang mengatur, namun jumlah perusahaan yang melakukan laporan keberlanjutan mengalami peningkatan setiap tahunnya dikarenakan adanya Pernyataan Standar Akuntansi Keuangan (PSAK) No.1 Tahun 2009 paragraf 12, dan peraturan lainnya (Wahyuni, 2015; Simbolon dan Memed, 2016).

Pada kenyataannya pengungkapan laporan keberlanjutan perusahaan hanya untuk meningkatkan jumlah pelaporan mereka dan memperkuat citra positif perusahaan dengan membuat laporan dengan desain yang menarik terlepas dari konten laporan itu sendiri (Villiers dan Alexander, 2014; Michelon, Pilanota dan Ricceri, 2015). Untuk itu, keterbukaan informasi harus menjadi masalah untuk dievaluasi oleh praktisi, akademisi dan regulator.

Banyak sekali penelitian yang meneliti tentang pemangku kepentingan utama terhadap pengungkapan tanggungjawab sosial. Namun, ada peneliti hanya menunjukkan dampak atau efek pengungkapan tanggungjawab sosial bukan transparansi kuantitas yang sebenarnya. Cowen, Ferreri, dan Parker (1987) serta Toms (2002) mengemukakan apabila hanya bergantung pada dampak pengungkapan saja akan memberikan kesimpulan yang salah. Untuk itu, sangat penting mengetahui apakah tekanan dari pemangku kepentingan utama, yang berbeda antar perusahaan akan meningkatkan informasi tanggungjawab sosial secara umum dalam laporan keberlanjutan. Hal inilah yang menjadi motivasi peneliti dalam melakukan penelitian ini.
Tujuan penelitian ini bukan untuk menentukan pemangku kepentingan utama di setiap perusahaan. Tujuan penelitian ini untuk mendapatkan bukti empiris apakah terdapat pengaruh pemangku kepentingan (pemegang saham, karyawan, pemerintah dan media) terhadap pengungkapan laporan keberlanjutan secara positif. Tanggungjawab sosial perusahaan yang baik adalah menerapkan praktik kebijakan keterlibatan pemangku kepentingan melalui hubungan timbal balik dengan para pemangku kepentingan mereka (Manetti, 2011).

\section{Kajian Pustaka dan Pengembangan Hipotesis Teori Pemangku Kepentingan}

Teori pemangku kepentingan adalah salah satu teori utama yang sering digunakan untuk menjadi dasar penelitian tentang laporan keberlanjutan (Sener, Varoglu dan anil, 2016; Rudyanto dan Siregar, 2018). Pada teori pemangku kepentingan ini menyatakan tanggungjawab organisasi tidak hanya kepada seluruh investor dan pemilik tetapi juga memperluas kepada seluruh pemangku kepentingan atau stakeholders (Sweeney dan Coughlan, 2011). Perusahaan harus menjaga hubungan dengan pemangku kepentingan (pemegang saham, pemerintah, media, karyawan, konsumen, supplier, analis, kreditur, masyarakat, dan pihak yang lainnya) dengan mengakomodasi keinginan dan kebutuhan pemangku kepentingan (Freeman dan Mcvea, 2001; Ghozali dan Chariri, 2007; Man, 2015).

Dalam hal tersebut, dalam memenuhi keinginan dan menyeimbangi kebutuhan pemangku kepentingan, perusahaan harus memisah-misahkan mana pemangku kepentingan yang harus diberi perhatian khusus (primary stakeholders) yang menyediakan sumber daya bagi perusahaan dan biasanya terdiri dari pemegang saham, investor, karyawan, pelanggan, pemasok, dan pemerintah; dan mana yang tidak perlu (secondary stakeholders) yang memiliki kapasitas untuk memobilisasi opini publik dalam mendukung atau menentang perusahaan dan terdiri dari regulator, lembaga non-pemerintah dan media (Clarkson, 1995; Astrid dan Veronica Slyvia, 2016).

Keterlibatan dari pemangku kepentingan yang akan memberikan tekanan akan berdampak terhadap pengungkapan laporan keberlanjutan dimana tekanan yang diberikan oleh primary stakeholders lebih besar daripada tekanan dari secondary stakeholders sehingga perusahaan berusaha dalam menjalankan tanggung 
jawab sosialnya dengan kebutuhan ataupun keinginan primary stakeholders (Astrid dan Veronica Slyvia, 2016). Tekanan ini juga berpengaruh terhadap pengungkapan tanggungjawab sosial perusahaan (Ullman, 1985; Gao et al., 2015), respon manajer kepada lingkungan bisnis yang ada, dan strategi untuk menjaga hubungan dengan pemangku kepentingan (Laplume, Sonpar dan Litz, 2008; Tarigan dan Semuel, 2014). Oleh karena itu, pengungkapan laporan keberlanjutan diharapkan dapat memenuhi keinginan dari pemangku kepentingan sehingga memberikan hubungan yang baik antara perusahaan dan pemangku kepentingan dengan begitu dapat tercapainya keberhasilan perusahaan dalam jangka panjang (Cahaya et al., 2017).

\section{Keterlibatan Pemangku Kepentingan}

Keterlibatan pemangku kepentingan sangat penting dalam laporan keberlanjutan, langkah yang sangat dasar dari proses pelaporan laporan keberlanjutan yaitu, keterlibatan pemangku kepentingan karena perannya dalam menerapakan materialitas dan relevansi informasi yang dikomunikasikan (Manetti, 2011).

Awal proses dalam pembuatan laporan keberlanjutan, pemangku kepentigan akan dilibatkan dalam memberikan pengungkapan kebutuhan dan harapan mereka, selama proses berlangsung pemangku kepentingan mendapat timbal balik dan kritik, dan selama proses publikasi laporan pemangku kepentingan mendapatkan konsultasi tentang usaha masa depan terkait isu-isu keberlanjutan dan siklus pelaporan mendatang (Isenmann dan Kim, 2006).

\section{Pemegang Saham}

Perusahaan yang berorientasi pada pemegang saham akan memberikan pengungkapan informasi yang transparansi, suatu laporan akan direspon positif oleh pemegang saham jika mampu memberikan informasi yang transparan dan memberikan kandungan informasi terkait kemampuan perusahaan dimasa mendatang (Jenawan dan Juniarti, 2015). Pemegang saham memiliki pengaruh besar dalam pengambilan keputusan manajerial, pengelolaan, permasalahan sosial, dan melampui keputusan investasi dengan memberikan isu-isu laporan keberlanjutan pada pertemuan pemegang saham tahunan (O'Rourke,
2003; Kimber dan Lipton, 2005; Yang dan Rivers, 2009).

\section{Karyawan}

Salah satu aset paling berharga bagi perusahaan adalah sumber daya manusia sebagai pemangku kepentingan yang paling berpengaruh untuk pelaporan keberlanjutan transparan (Fernandez-Feijoo dan Romero, 2014; Rudyanto dan Siregar, 2018; Alfaiz dan Aryati, 2019) dan pelaporan lingkungan (Huang dan Kung, 2010) jika perusahaan besungguh-sungguh dalam laporan keberlanjutan, akan meningkatkan penilaian karyawan terhadap pekerjaan atau situasi kerja, memotivasi karyawan dan memandang perusahaan sudah memenuhi hak-hak karyawannya dengan begitu tingkat perputaran karyawan menurun sehingga dapat meningkatkan produktivitas perusahaan (Barakat et al., 2016).

Laporan keberlanjutan dapat membantu ikatan antara perusahaan dengan karyawan, seperti halnya beberapa karyawan mengalokasikan waktunya untuk terlibat dalam isu-isu sosial baik itu perilaku sosial, seperti dipaksa lembur dan jam kerja yang panjang, kondisi kerja yang berbahaya dan intimidasi serikat buruh yang akan menyebabkan tuduhan serius atau litigasi yang bisa merusak keuangan dan reputasi perusahaan (Yu, 2009; Li, Lin, dan Yang, 2016).

\section{Pemerintah}

Pemerintah termasuk bagian dari pemangku kepentingan yang dianggap paling mempengaruhi perusahaan karena pemerintah menekan perusahaan untuk aktivitas CSR dengan cara membuat regulasi (Huang dan Kung, 2010; Lin, dan Yang, 2016; Wang et al., 2017). Mengingat bahwa pemerintah sekarang memiliki peraturan yang berkaitan dengan laporan keberlanjutan, dan baru-baru ini juga dirilis program khusus mengenai pengembangan kualitas dan produktivitas karyawan, dengan regulasi laporan keberlanjutan tersebut, diketahui dapat membantu dalam meningkatkan transparansi pelaporan (Depnakertrans, 2008; Amran \& Devi, 2008; Cahaya et al., 2015; Wang et al., 2017).

Perusahaan dengan kepemilikan pemerintah berpotensi ditekankan untuk mengungkapkan informasi lebih lanjut tentang masalah ketenagakerjaan dan hubungan signifikan antara kepemilikan pemerintah dengan masyarakat, sehingga praktik 
pengungkapan didokumentasikan dengan baik dalam literatur dan mempermudah pemerintah dalam menekan perusahaan dalam menjalankan aktivitas sosial (Eng dan Mak, 2003; Firer dan Williams, 2005; He et al., 2017).

\section{Media}

Media dapat membantu mencegah perilaku perusahaan yang tidak bertangggungjawab secara sosial, sehingga bagi perusahaan untuk membangun legitimsai melalui paparan positif dari media, media harus memainkan peran pokoknya dalam mempromosikan kinerja lingkungan perusahaan yang telah diorientasikan dalam pengungkapan sustainability report (Kassinis dan Vafeas, 2006; Weaver, Trevino, dan Cochran, 1999; Campbell, 2007). Media akan memanfaatkan kekuatan positif perusahaan dalam melindungi manfaat sosial publik agar perusahaan lebih berkomitmen terhdapa perlindungan lingkungan (Lu dan Abeysekera, 2014).

\section{Laporan Keberlanjutan}

Global Reporting Initiative (GRI) mendefinisikan pelaporan keberlanjutan sebagai sistem praktik pelaporan perusahaan dan institusi untuk mengukur, memahami dan mengungkapkan informasi sosial, lingkungan dan ekonomi sebagai bagian dari tanggungjawab semua pemangku kepentingan eksternal atau internal terkait dengan pencapaian organisasi dari tujuan pembangunan berkelanjutan. Pedoman G4 digunakan sebagai standar untuk mengungkapkan tanggung jawab perusahaan, yang terdiri dari: aspek kinerja ekonomi, aspek kinerja lingkungan, aspek praktik ketenagakerjaan dan pekerjaan yang layak, aspek hak asasi manusia, aspek komunitas, dan dimensi tanggung jawab produk.

Tujuan dari pengungkapan laporan keberlanjutan adalah meningkatkan prospek perusahaan dengan membantu mewujudkan transparansi, meningkatkan nama perusahaan, peka dan peduli terhadap masyarakat dan lingkungan tidak terpaku pada keuntungannya saja, mengurangi risiko kerugian, meningkatkan kemampuan dan kesiapan terhadap pemangku kepentingan, dan sebagai analisis bagi investor.

Pengungkapan laporan keberlanjutan yang baik terdiri atas dua kategori pengungkapan yaitu standar umum dan standar khusus. Standar khusus mengatur pengungkapan yang dilaporkan perusahaan dibagi ke dalam 3 kategori. Kategori tersebut meliputi kategori ekonomi, kategori lingkungan dan kategori sosial (GRI, 2013).

\section{Global Reporting Initiative (GRI)}

Global Reporting Initiative (GRI) adalah suatu kerangka yang dibuat untuk terbentuknya suatu laporan keberlanjutan suatu perusahaan. Dengan adanya standar khusus yang menjadi pedoman laporan keberlanjutan dapat menghasilkan informasi yang handal, relevan serta terstandarisasi dalam upaya pengambilan keputusan bagi pihak pemangku kepentingan. GRI G4 merupakan generasi keempat dalam pedoman pembuatan laporan keberlanjutan yang dikeluarkan pada Mei 2013. Terbitnya GRI G4 menjadi hasil tertinggi dari pembahasan dan pertukaran pemahaman dari pemangku kepentingan serta dari beberapa pakar dunia baik dari perusahaan, masyarakat sipil, organisasi buruh, akademisi, dan lembaga keuangan. Tujuan GRI G4 ini adalah menjadi pedoman agar terbentuknya laporan keberlanjutan yang bermakna, akurat, handal, dan relevan dalam suatu praktik standar (GRI, 2013).

\section{Hipotesis}

H1: Keterlibatan pemegang saham sebagai pemangku kepentingan berpengaruh positif terhadap pengungkapan laporankeberlanjutan.

H2: Keterlibatan karyawan sebagai pemangku kepentingan berpengaruh positif terhadap pengungkapan laporan keberlanjutan.

H3: Keterlibatan pemerintah sebagai pemangku kepentingan berpengaruh positif terhadap pengungkapan laporan keberlanjutan.

H4: Keterlibatan media sebagai peamngku kepentingan berpengaruh positif terhadap pengungkapan laporan keberlanjutan.

\section{Metode Penelitian}

\section{Desain Penelitian}

Tujuan dari penelitian ini yaitu untuk mengetahui apakah terdapat pengaruh dari keterlibatan pemangku kepentingan terhadap pengkungkapan laporan keberlanjutan berdasarkan GRI - G4. Dalam penelitian ini peneliti menggunakan jenis penelitian kuantitatif dengan tingkat intervensi 
minimal, disebabkan peneliti hanya mengumpulkan data laporan keberlanjutan perusahaan. Unit analisis yang digunakan dalam penelitian ini adalah organisasi, yaitu semua perusahaan yang terdaftar di BEI dari tahu 20162019. Horizon waktu dalam penelitian ini adalah longitudinal, karena peneliti melakukan pengumpulan data hanya pada beberapa periode laporan berkelanjutan baik dari 2016 - 2019.

\section{Populasi dan Sampel Penelitian}

Populasi dalam penelitian ini adalah semua perusahaan Indonesia yang terdaftar di Bursa Efek Indonesia (BEI) tahun 2016 - 2019 dengan total 694 perusahaan. Sampel adalah sekelompok atau beberapa bagian dan karakteristik yang dimiliki oleh suatu populasi (Sugiyono, 2013:120). Metode pengambilan sampel dalam penelitian ini, menggunakan non-probability sampling dengan teknik purposive sampling karena, untuk mendapatkan sampel yang sesuai dengan kriteria yang telah ditetapkan oleh peneliti.

\section{Proses Pengambilan Sampel}

\begin{tabular}{|l|c|}
\hline \multicolumn{1}{|c|}{ Keterangan } & $\begin{array}{c}\text { Jumlah } \\
\text { Peusahaan }\end{array}$ \\
\hline $\begin{array}{l}\text { Perusahaan yang telah terdaftar di Bursa Efek } \\
\text { Indonesia tahun 2016 - 2019. }\end{array}$ & 694 \\
\hline $\begin{array}{l}\text { Perusahaan yang tidak mempublikasikan laporan } \\
\text { keberlanjutan dengan berdiri sendiri (stand alone) } \\
\text { tahun 2016 - 2019. }\end{array}$ & $(621)$ \\
\hline $\begin{array}{l}\text { Perusahaan yang tidak melaporkan laporan } \\
\text { keberlanjutan secara berturut - turut pada tahun } \\
\text { 2016 - 2019. }\end{array}$ & $(38)$ \\
\hline Perusahaan yang dijadikan sampel & 35 \\
\hline $\begin{array}{l}\text { Total sampel penelitian selama 4 tahun } \\
\text { pengamatan }\end{array}$ & 140 \\
\hline
\end{tabular}

Sumber Data : Data diolah (2020)

\section{Sumber dan Teknik Pengambilan Data}

Dalam penelitian ini peneliti menggunakan sumber data sekunder yang sesuai dengan tujuan penelitian. Terdapat beberapa teknik pengumpulan data yaitu, wawancara, kuesioner, observasi, dokumentasi, atau metode uji coba (test) (Suharso, 2009:82). Pada penelitian ini peneliti menggunakan teknik dokumentasi berupa data sekunder dalam bentuk laporan, surat kabar, file atau lainnya guna memenuhi informasi data sebagai kepentingan variabel sehingga dapat meningkatkan nilai dan keakuratan data penelitian (Suharso, 2009:104). Pengumpulan data diperoleh dari laporan keberlanjutan perusahaan yang dipublikasikan dari situs resmi Bursa Efek Indonesia (BEI): www.idx.co.id. dan website situs resmi dari masing - masing perusahaan untuk tahun $2016-2019$.

\section{Operasional Variabel \\ Pemegang Saham}

Pengukuran klasifikasi pemegang saham sebagai pemangku kepentingan dalam perusahaan menggunakan pengukuran dari Thomsen dan Pederson, 2006; Hartanto dan Purwartiningsih, 2014; Lu dan Abeysekera, 2014 yaitu, dengan struktur tingkat kepemilikan saham. Tingkatan tersebut diukur dengan persentase kepemilikan saham dari pemegang saham terbesar pada akhir tahun. Kepemilikan saham terbesar menjadikan mekanisme internal keteraturan manajemen sebagai salah satu mekanisme untuk meningkatkan pengawasan karena dengan kepemilikan yang besar akan menjadikan pemegang saham yang memiliki jalan informasi secara signifikan dalam menyeimbangi keuntungan informasi yang dimiliki manajemen (Ooghe dan Langhe, 2002).

Pemegang Saham $=$ Persentase Kepemilikan Saham Terbesar

\section{Karyawan}

Karyawan salah satu pemangku kepentingan yang terdapat dalam pengungkapan laporan keberlanjutan perusahaan, jika laporan keberlanjutan dapat diimplementasikan karyawan akan memenuhi kebutuhannya dan perusahaan mendapatkan keuntungan yang maksimal (Du, Bhattacharya, dan Sen, 2014; Guse et al., 2016). Untuk mengukur pengaruh dari keterlibatan karyawan, yaitu dengan jumlah karyawan (Saka dan Noda, 2013; Li, Lin, dan Yang, 2016; Rudyanto dan Siregar, 2018).

\section{Pemerintah}

Peningkatan pengungkapan laporan keberlanjutan dapat dipengaruhi dari pengendalian regulasi yang ditetapkan pemerintah kepada perusahaan untuk menjadi perusahaan yang lebih aktif dalam laporan keberlanjutan (Wang at al., 2017; He et al., 2017). Dalam penelitian Lu dan Abeysekera (2014) untuk mengukur pengaruh pemerintah adalah apabila 
perusahaan tersebut dimiliki oleh pemerintah akan diberi poin 1 , sedangkan yang lainnya diberi poin 0 . Tetapi, untuk penelitian ini pengukuran yang digunakan adalah asumsi jika perusahaan memiliki kedudukan kepemilikan saham pemerintah maka di beri poin 1, sedangkan jika tidak akan diberi 0 (Said, Zainuddin, \& Haron, 2009; Cahaya et al., 2012).

\section{Media}

Media dipandang sebagai pemangku kepentingan dalam membangun kepercayaan antara perusahaan dan pemangku kepentingan lainnya. Visibilitas perusahaan dari media massa dapat ditentukan melalui berita yang diproksikan dengan jumlah berita mengenai perusahaan tersebut pada mesin pencari Google pada tahun pelaporan (Garcia-Sanchez et al., 2014).

\section{Pengungkapan Laporan Keberlanjutan}

Dalam penelitian ini variabel pengungkapan laporan keberlanjutan diukur dengan Sustainability Report Disclosure Index (SRDI) berdasarkan GRI G4 yang sebelumnya dilakukann oleh Said, Zainuddin, \& Haron (2009), Dong et.al, (2015), Nasution dan Adhariani (2016) sebagai pengukuran kualiatas laporan keberlanjutan. Skala pemberian skor dari 0 sampai 1. Skor 0 diberikan jika perusahaan tidak mengungkapkan item yang dimaksud dan skor 1 diberikan jika perusahaan mengungkapkan item yang dimaksud berlaku untuk standar umum dan khusus yang telah ditetapkan GRI-G4 (Nugraha dam Danayani, 2013; Simbolon dan Memed, 2016). total indikator Global Initiative Reporting (GRI) G4 guideline sebanyak 150 item. Rumus diclosure index sebagai berikut:

$$
\mathrm{SRDI}=\frac{n}{k}
$$

Keterangan:

$$
\begin{array}{ll}
\text { SRDI: } & \text { Sustainability Report Disclosure } \\
& \text { Index } \\
\mathrm{n}: & \text { jumlah item yang diungkapkan } \\
\mathrm{k}: & \text { jumlah item yang diharapkan } \\
& \text { diungkapkan }
\end{array}
$$

\section{Metode Analisis}

Analisis regresi linier berganda dalam penelitian ini digunakan untuk menguji pengaruh variabel independen yaitu, pemegang saham, karywan, pemerintah dan media terhadap variabel dependen

\begin{tabular}{|c|c|}
\hline Y & $\begin{array}{c}=\text { Indeks Pengungkapan Laporan } \\
\text { Keberlanjutan }\end{array}$ \\
\hline $\mathrm{a}$ & $=$ Konstanta \\
\hline b1 b2 b3 b4 & $=$ Koefisien Regresi \\
\hline $\mathrm{x} 1$ & $=$ Pemegang Saham \\
\hline $\mathrm{x} 2$ & = Karyawan \\
\hline $\mathrm{x} 3$ & $=$ Pemerintah \\
\hline$x 4$ & $=$ Media \\
\hline & $=$ Error \\
\hline
\end{tabular}
pengungkapan laporan keberlanjutan. Metode statistik dari model persamaan regresi linier berganda secara sistematis dirumuskan sebagai berikut:

$$
Y=a+b 1 \times 1+b 2 \times 2+b 3 \times 3+b 4 \times 4+e
$$

Keterangan :

\section{Hasil Dan Pembahasan \\ Deskripsi Objek Penelitian}

Tujuan penelitian ini untuk menguji apakah terdapat pengaruh pemegang saham, karyawan, pemerintah dan media terhadap pengungkapan laporan keberlanjutan perusahaan yang terdaftar di BEI dari tahun 2016-2019. Objek penelitian menggunakan metode purposive sampling dengan menentukan kriteria-kriteria yang sudah ditentukan. Berdasarkan metode kriteria didapatkan sampel 35 perusahaan dengan 140 laporan pada perusahaan yang terdaftar di BEI dari tahun 2016-2019.

Analisis data dilakukan dengan menggunakan metode analisis regresi linier berganda. Tahap awal yang dilakukan yaitu, pengujian asumsi klasik diantara lain uji normalitas, uji multikolinieritas, uji heteroskedastisitas dan uji autokorelasi. Selanjutnya, dilakukannya uji hipotesis dengan uji statistik $t$ dan uji analisis regresi berganda dengan melihat nilai koefisiean, nilai $\mathrm{t}$ dan nilai signifikansi pada 0,05 $(5 \%)$.

Berdasarkan hasil uji asumsi klasik membuktikan bahwa data penelitian berdistribusi normal dan bebas dari gejala multikolinieritas, heteroskedastisitas dan auto korelasi. 


\section{Hasil Pengujian Regresi Linier Berganda}

Tabel 1

Hasil Regresi Linier Berganda

Coefficients $^{\mathrm{a}}$

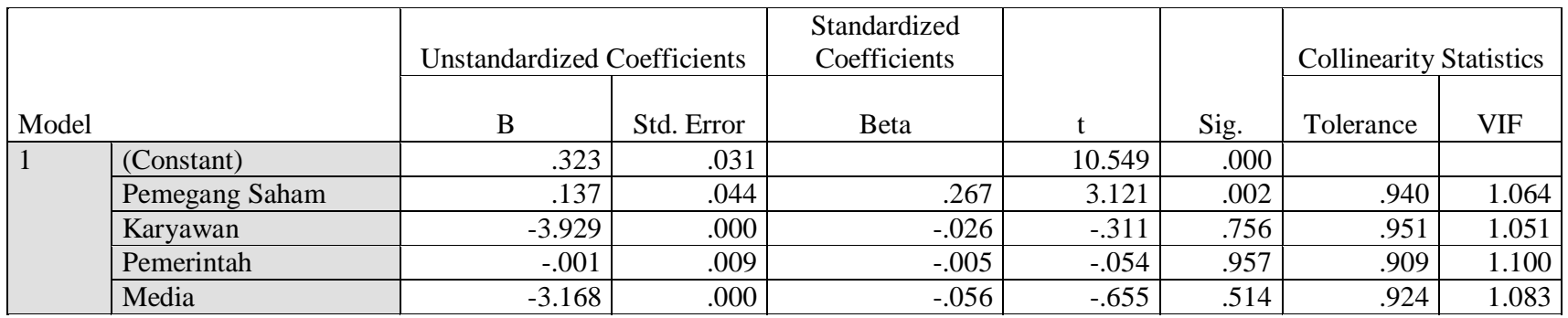

a. Dependent Variable: Pengungkapan Laporan Kebelanjutan

Sumber: Output SPSS (2020)

Dari hasil perhitungan pada tabel di atas, maka didapatkan persamaan regresi linier berganda sebagai berikut:

\section{$Y=0,323+0,137 X 1-3.929 X 2-0,001 X 3-3.168 X 4+e$}

Hasil dari persamaan model tersebut, dapat disimpulkan sebagai berikut:

1. Nilai konstanta sebesar 0,323. Hasil ini dapat diartikan bahwa apabila besarnya nilai seluruh variabel independen (pemegang saham, karyawan, pemerintah, media) adalah 0 , maka besarnya nilai pengungkapan laporan keberlanjutan akan sebesar 0,323.

2. Nilai koefisien regresi variabel pemegang adalah sebesar 0,137. Hasil ini dapat diartikan bahwa apabila variabel pemegang saham naik satu satuan, maka pengungkapan laporan keberlanjutan akan meningkat sebesar 0,137 dengan asumsi semua variabel independen lain konstan.

3. Nilai koefisien regresi karyawan adalah sebesar 3.929. Hasil ini tidak dapat diartikan dikarenakan penelitian ini tidak mampu dan tidak mendukung signifikansi dari hasil penelitian

4. Nilai koefisien regresi pemerintah adalah sebesar $-0,001$. Hasil ini tidak dapat diartikan dikarenakan penelitian ini tidak mampu dan tidak mendukung signifikansi dari hasil penelitian

5. Nilai koefisien regresi media adalah sebesar 3.168. Hasil ini tidak dapat diartikan dikarenakan penelitian ini tidak mampu dan tidak mendukung signifikansi dari hasil penelitian

\section{Uji Koefisien Determinasi $\left(\mathbf{R}^{2}\right)$}

Hasil uji determinasi $\left(\mathrm{R}^{2}\right)$ pada tabel 4.9 menjelaskan bahwa nilai $R$ Square sebesar 0,071 atau $7,1 \%$. Nilai tersebut menunjukkan bahwa variabel pemegang saham, karyawan, pemerintah, dan media hanya mampu menjelaskan variabel pengungkapan laporan keberlanjutan 7,1\% dan sisanya sebesar $92,9 \%$ dipengaruhi oleh faktor-faktor lain yang tidak dimasukkan dalam model regresi.

Tabel 2

Hasil Uji Koefisien Determinasi Model Summary $^{\mathrm{b}}$

\begin{tabular}{|l|r|r|r|r|}
\hline Model & R & R Square & \multicolumn{1}{c|}{ Adjusted R Square } & Std. Error of the Estimate \\
\hline 1 & $.267^{\mathrm{a}}$ & .071 & .044 &, 05322 \\
\hline
\end{tabular}

a. Predictors: (Constant), Media, Karyawan, Pemegang Saham, Pemerintah

b. Dependent Variable: Pengungkapan Laporan Keberlanjutan

Sumber: Output SPSS (2020) 


\section{Uji Statistik t}

\section{Tabel 3}

Hasil Uji Statistik t

Coefficients $^{\mathrm{a}}$

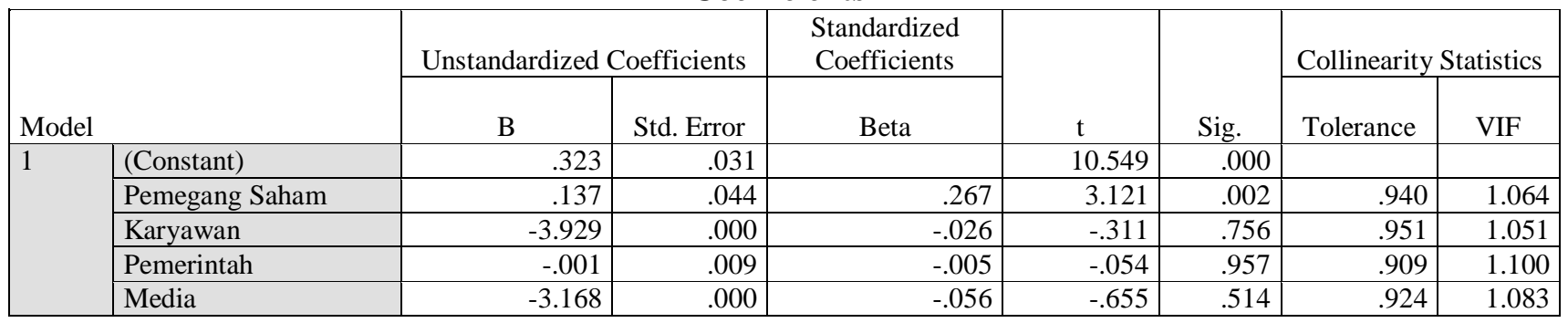

b. Dependent Variable: Pengungkapan Laporan Kebelanjutan

Sumber: Output SPSS (2020)

Berdasarkan tabel di atas, dapat disimoulkan bahwa:

1. Pemegang Saham

Pada tabel 4.10 menunjukkan bahwa nilai signifikansi sebesar 0,002 lebih kecil dari tingkat signifikansi 0,05 dan $t_{\text {hitung }}$ sebesar $3.121>t_{\text {tabel }}$ sebesar 1.656. Dengan demikian, terdapat bukti bahwa keterlibatan pemegang saham berpengaruh signifikan terhadap pengungkapan laporan keberlanjutan. Nilai koefisien regresi sebesar 0,137 menunjukkan adanya hubungan positif antara keterlibatan pemegang saham dengan pengungkapan laporan keberlanjutan. Hasil tersebut konsisten dengan hipotesis 1, dimana memprediksi adanya pengaruh positif antara pemegang saham den dengan pengungkapan laporan keberlanjutan. Dengan demikian H1 diterima.

2. Karyawan

Pada tabel 4.10 menunjukkan bahwa nilai signifikansi sebesar 0,756 lebih besar dari tingkat signifikansi 0,05 dan dan $t_{\text {hitung }}$ sebesar $-0,311<$ $t_{\text {tabel }}$ sebesar 1.656. Dengan demikian, terdapat bukti bahwa keterlibatan karyawan tidak berpengaruh signifikan terhadap pengungkapan laporan keberlanjutan. Nilai koefisien regresi sebesar -3,929 menunjukkan adanya hubungan negatif antara keterlibatan karyawan dengan pengungkapan laporan keberlanjutan. Hasil tersebut tidak konsisten dengan hipotesis 2, dimana memprediksi adanya pengaruh positif antara karyawan dengan pengungkapan laporan keberlanjutan. Dengan demikian H2 ditolak.

3. Pemerintah (H3)
Pada tabel 4.10 menunjukkan bahwa nilai signifikansi sebesar 0,957 lebih besar dari tingkat signifikansi 0,05 dan $\mathrm{t}_{\text {hitung }}$ sebesar- $0,054<\mathrm{t}_{\text {tabel }}$ sebesar 1.656. Dengan demikian, terdapat bukti bahwa keterlibatan pemerintah tidak berpengaruh signifikan terhadap pengungkapan laporan keberlanjutan. Nilai koefisien regresi sebesar 0,001 menunjukkan adanya hubungan negatif antara keterlibatan pemerintah dengan pengungkapan laporan keberlanjutan. Hasil tersebut tidak konsisten dengan hipotesis 3, dimana memprediksi adanya pengaruh positif antara pemerintah dengan pengungkapan laporan keberlanjutan. Dengan demikian H3 ditolak.

4. Media

Pada tabel 4.10 menunjukkan bahwa nilai signifikansi sebesar 0,514 lebih besar dari tingkat signifikansi 0,05 dan $t_{\text {hitung }}$ sebesar $-0,655<t_{\text {tabel }}$ sebesar 1.656. Dengan demikian, terdapat bukti bahwa keterlibatan media tidak berpengaruh signifikan terhadap pengungkapan laporan keberlanjutan. Nilai koefisien regresi sebesar 3,168 menunjukkan adanya hubungan negatif antara keterlibatan media dengan pengungkapan laporan keberlanjutan. Hasil tersebut tidak konsisten dengan hipotesis 4, dimana memprediksi adanya pengaruh positif antara pemerintah dengan pengungkapan laporan keberlanjutan. Dengan demikian H4 ditolak.

\section{Pembahasan Hasil Pengujian Hipotesis}

\section{Pengaruh Pemegang Saham terhadap} Pengungkapan Laporan Keberlanjutan

Hasil Penelitian membuktikan bahwa keterlibatan pemegang saham sebagai pemangku kepentingan 
berpengaruh positif terhadap pengungkapan laporan keberlanjutan. Hasil penelitian ini mendukung pernyataan Li et al (2016), Kumar et al. (2015), dan Prado et al. (2009) yang mengungkapkan bahwa keterlibatan pemegang saham mempengaruhi pengungkapan laporan keberlanjutan perusahaan secara positif. Hal tersebut mengindikasikan bahwa pemegang saham bereaksi terhadap pengungkapan laporan keberlanjutan yang di dorong dari pasar keuangan agar meningkat tingkat kepercayaan pemegang saham dengan meningkatkan level pengungkapan laporan. Dengan demikian, pemegang saham di Indonesia sudah memperhatikan laporan keberlanjutan dari segi lingkungan, sosial, ekonomi dalam menentukan perusahaan mana yang diinvestasikan.

\section{Pengaruh Karyawan terhadap Pengungkapan Laporan Keberlanjutan}

Hasil penelitian membuktikan bahwa keterlibatan karyawan tidak berpengaruh positif terhadap pengungkapan laporan keberlanjutan. Karyawan di Indonesia cenderung melihat tanggungjawab sosial dan laporan keberlanjutan sebagai sesuatu yang merugikan perusahaan dan mengurangi nilai perusahaan.

Hal ini sesuai dengan Ceil (2012) yang menyatakan bahwa karyawan cenderung menganggap tanggungjawab sosial dapat menambah beban perusahaan sehingga dapat mengurangi gaji mereka. Selain itu tanggungjawab sosial juga membuat karyawan merasa tersisih karena praktik tanggungjawab sosial perusahaan tidak disosialisasikan dengan baik. Walaupun pengungkapan jumlah dan tingkat perekrutan karyawan baru dan perputaran karyawan menjadi komponen yang paling banyak diungkapkan (92\%) dalam laporan yang menggunakan GRI G4 namun pengungkapan itu tidak ditujukan kepada karyawan sebagai pembaca laporan keberlanjutan tapi kepada pihak lain

\section{Pengaruh Pemerintah terhadap Pengungkapan Laporan Keberlanjutan}

Hasil penelitian membuktikan bahwa pemerintah tidak berpengaruh positif terhadap pengungkapan laporan kebelanjutan. Kebanyakan perusahaan di Indonesia tidak melaporkan informasi terkait tenaga kerja baik itu hubungan pekerja/manajemen, kesehatan dan keselamatan kerja, pelatihan pendidikan dan keanekaragaman, dan praktik pengungkapan kesempatan yang sama melalui penegakan atau tekanan dari pemerintah.

Tercatat dalam literatur bahwa regulasi penegakan hukum di Indonesia lemah, pengungkapan laporan keberlanjutan perusahaan sebenarnya tetap bersifat sukarela karena peraturan di Indonesia tidak menentukan item standar SR mana yang harus dilakukan dan dikomunikasikan dengan lebih bijak. Peraturan terkait laporan keberlanjutan (misalnya UU No. 40/2007) telah menyebutkan hukuman untuk kegagalan perusahaan dalam mengungkapan informasi terkait tanggungjawab ekonomi, sosial, dan lingkungan, tetapi tidak jelas mengartikulasikan konsekuensi spesifik atau hukuman yang akan dijatuhkan. Ini menunjukkan bahwa masih ada kelemahan terkait peraturan pengungkapan laporan keberlanjutan di Indonesia. Oleh karena itu, logis bahwa perusahaan Indonesia tidak berkomunikasi informasi terkait tenaga kerja dalam aspek pelaporan melalui penegakan pemerintah.

\section{Pengaruh Media terhadap Pengungkapan Laporan Keberlanjutan}

Hasil penelitian membuktikan bahwa keterlibatan media tidak berpengaruh positif terhadap pengungkapan laporan keberlanjutan. Hal ini diindikasikan oleh kecenderungan insan media dalam membuat liputan cenderung mempublikasikan isu-isu besar saja karena anggapan bahwa isu-isu kecil kurang menjadi perhatian masyarakat.

Selain itu, banyak terjadi di Indonesia media menjadi platform yang salah dipergunakan oleh masyarakat, walaupun media menjadi citra perusahaan tetapi tidak sebagian besar investor atau masyarakat memiliki kepercayaan yang tinggi. Kurangnya edukasi dan profesionalis wartawan dalam meliput permasalahan besar seperti pencemaran lingkungan yang dilakukan perusahaan sehingga memicu permasalahan sosial antara perusahaan dan wartawan yang telah menjatuhkan citra positif perusahaan atas dugaan berita hoax.

\section{Kesimpulan, Keterbatasan Dan Saran Kesimpulan}

Penjelasan dan pembahasan yang dapat ditarik kesimpulan sebagai berikut: 
1) Keterlibatan pemegang saham memiliki pengaruh positif yang signifikan terhadap pengungkapan laporan keberlanjutan. Dapat dibuktikan dari hasil uji statistik yang sudah dilakukan dimana variabel pemegang saham memiliki koefisien regresi sebesar 0,137 dengan tingkat signifikansi yang lebih kecil dari 0,05 yaitu sebesar 0,002.

2) Keterlibatan karyawan tidak memiliki pengaruh positif yang signifikan terhadap pengungkapan laporan keberlanjutan. Dapat dibuktikan dari hasil uji statistik yang sudah dilakukan dimana variabel karyawan memiliki koefisien regresi sebesar -3.929 dengan tingkat signifikansi yang lebih besar dari 0,05 yaitu sebesar 0,756 .

3) Keterlibatan pemerintah tidak memiliki pengaruh positif yang signifikan terhadap pengungkapan laporan keberlanjutan. Dapat dibuktikan dari hasil uji statistik yang sudah dilakukan dimana variabel pemerintah memiliki koefisien regresi sebesar 0,001 dengan tingkat signifikansi yang lebih besar dari 0,05 yaitu sebesar 0,957 .

4) Keterlibatan media tidak memiliki pengaruh positif yang signifikan terhadap pengungkapan laporan keberlanjutan. Dapat dibuktikan dari hasil uji statistik yang sudah dilakukan dimana variabel media memiliki koefisien regresi sebesar -3.168 dengan tingkat signifikansi yang lebih besar dari 0,05 yaitu sebesar 0,514 .

5) Hasil penelitian ini tidak mampu mendukung hipotesis yang telah disusun sebelumnya dan dibuktikan dengan nilai signifikansi dan nilai koefisiensi negatif yang terdapat pada variabel karyawan, media dan pemerintah

\section{Keterbatasan}

Keterbatasan yang dimiliki peneliti dalam melakukan penelitian, diantaranya sebagai berikut:

1) Sampel yang digunakan dalam penelitian terlalu sedikit hanya ada 35 perusahaan dan empat periode saja. Namun dengan keterbatasan waktu dalam pelaksanaan penelitian S-1 maka data dengan empat periode laporan keberlanjutan perusahaan dianggap cukup.

2) Keterbatasan dalam pengumpulan dan pengukuran media. Media yang digunakan dalam penelitian ini terbatas pada berita yang hanya ada di mesin pencarian Google saja, masih bisa dicari dari web perusahaan dan media cetak lainnya.

\section{Saran}

saran untuk penelitian selanjutnya, yaitu:

1) Penelitian ini hanya menggunakan empat pemangku kepentingan, yaitu pemegang saham, karyawan, pemerintah, dan media. Penelitian selanjutnya dapat mempertimbangkan untuk menggunakan variabel di luar dari variabel penelitian ini.

2) Penelitian ini menggunakan pengungakapan GRI dengan metode skoring. Penelitian selanjutnya dapat menggunakan penggukapan GRI dengan jumlah halaman, dan ada tidaknya GRI Application Check dari pihak independen.

3) Penelitian selanjutnya sebaiknya memperluas sampel penelitian tidak hanya pada laporan keberlanjutan saja tapi pada laporan tahunan perusahaan.

4) Penelitian selanjutnya diharapkan menambah jumlah periode tahun dari perusahaan.

\section{Daftar Pustaka}

Amran, A., \& Devi, S. S. (2008). The impact of government and foreign affiliate influence on corporate social reporting. Managerial Auditing Journal, 23(4), 386-404. https://doi.org/10.1108/02686900810864327

Andriof, J., Waddock, S., Husted, B., \& Rahman, S. S. (2002). Unfolding Stakeholder Thinking: Theory, Responsibility and Engagement (edisi satu). Sheffield, UK: Greenleag Publishing.

Barakat, S. R., Isabella, G., Boaventura, J. M. G., \& Mazzon, J. A. (2016). The influence of corporate social responsibility on employee satisfaction. Management Decision Journal, 54(9), 23252339. https://doi.org/10.1108/MD-05-2016-0308

BEI. (n.d.). Retrieved from https://www.idx.co.id/

Belkaoui, A., \& Karpik, P. G. (1989). Determinants of the Corporate Decision to Disclose Social Information. Accounting,Auditing \& Accountability Journal, 2(1), 36-51. https://doi.org/10.1108/09513578910132240

Betts, T. K., Wiengarten, F., \& Tadisina, S. K. (2015). Exploring the impact of stakeholder pressure on environmental management strategies at the plant level: what does industry have to do with it? Journal of Cleaner Production, 92, 282-294. 
https://doi.org/10.1016/j.jclepro.2015.01.002

Bitektine, A. (2011). TOWARD A THEORY OF SOCIAL JUDGMENTS OF ORGANIZATIONS : THE CASE OF LEGITIMACY , REPUTATION , AND STATUS. Academy of Management Review, $36(1)$, $151-179$. https://doi.org/10.5465/amr.2009.0382

Branco, M. C., \& Rodrigues, L. L. (2008). Factors Influencing Social Responsibility Disclosure by Portuguese Companies. Journal of Business 83(4), 685-701. https://doi.org/10.1007/s10551-007-9658

Cahaya, F. R., Porter, S. A., Tower, G., \& Brown, A. (2012). Indonesia ' s low concern for labor issues. Social Responsibility Journal, 8(1), 114132.

\section{https://doi.org/10.1108/17471111211196610}

Cahaya, F. R., Porter, S. A., Tower, G., \& Brown, A. (2015). The Indonesian Goverment's coercive pressure on labour disclosures: conflicting interests or goverment ambivalence? Sustainability Accounting, Management and Policy Journal, 6(4), 475-497. https://doi.org/10.1108/SAMPJ-09-2014-0051

Cahaya, F. R., Porter, S. A., Tower, G., \& Brown, A. (2017). Coercive Pressures on Occupational Health and Safety Disclosures. Journal of Accounting in Emerging Economies, 7(3), 318336. https://doi.org/10.1108/jaee-04-2015-0032

Campbell, J. L. (2007). WHY WOULD CORPORATIONS BEHAVE IN SOCIALLY RESPONSIBLE WAYS ? AN INSTITUTIONAL THEORY OF CORPORATE SOCIAL RESPONSIBILITY. Academy of Management Review, 32(3), 946-967.

Ceil, C. (2012). Employees and Corporate Social Responsibility. SSRN Electronic Journal. https://doi.org/10.2139/ssrn.2112654

Chau, G. K., \& Gray, S. J. (2002). Ownership structure and corporate voluntary disclosure in Hong Kong and Singapore. The Internasional Journal of Accounting, 37(2), 247-265. https://doi.org/10.1016/S0020-7063(02)00153-X

Chiu, T.-K., \& Wang, Y.-H. (2014). Determinants of
Social Disclosure Quality in Taiwan: An Application of Stakeholder Theory. Journal of Business Ethics, 129(2), 379-398. https://doi.org/10.1007/s10551-014-2160-5

Cho, C. H., Michelon, G., \& Patten, D. M. (2012). Enhancement and obfuscation through the use of graphs in sustainability reports. Sustainability Accounting , Management and Policy Journal, 3(1), 74-88. https://doi.org/10.1108/20408021211223561

Choi, J.-S. (1999). An investigation of the initial voluntary environmental disclosures made in Korean semi-annual financial reports. Pacific Accounting Review, 11(73-102).

Clarkson, Max, B, E. (1995). A Stakeholder Framework for Analyzing and Evaluating Corporate Social Performance, 20(1), 92-117.

Cormier, D., \& Magnan, M. (2013). The Economic Relevance of Environmental Disclosure and its Impact on Corporate Legitimacy: An Empirical Investigation. Business Strategy and the Environment, 24(6), 431-450. https://doi.org/10.1002/bse.1829

Cowen, S. S., Ferreri, L. B., \& Parker, L. D. (1987). The impact of corporate characteristics on social responsibility disclosure: A typology and frequency-based analysis. Accounting, Organizations and Society, 12(2), 111-122. https://doi.org/10.1016/0361-3682(87)90001-8

Dissanayake, D., Tilt, C., \& Xydias-lobo, M. (2016). Sustainability reporting by publicly listed companies in Sri Lanka. Journal of Cleaner Production, 129, 169-182. https://doi.org/10.1016/j.jclepro.2016.04.086

Donaldson, T., \& Preston, L. E. (1995). The Stakeholder Theory of the Corporation: Concepts, Evidence, and Implications Author ( s ): Thomas Donaldson and Lee E. Preston Source: The Academy of Management Review, Vol . 20 , No . 1 ( Jan ., 1995 ), pp . 65-91 Published by : Academy of Manag. The Academy of Management Review, 20(1), 65-91. Retrieved from https://www.jstor.org/stable/258887 Accessed: 12 Desember 2019

Du, S., Bhattacharya, C. B., \& Sen, S. (2014). 
Corporate Social Responsibility, Multi-faceted Job-Products , and Employee Outcomes. Journal of Business Ethics, 131(2), 319-335. https://doi.org/10.1007/s10551-014-2286-5

Dutta, S., Lawson, R., \& Marcinko, D. (2012). Paradigms for Sustainable Development: Implications of Management Theory. Corporate Social Responsibility and Enviromental Management, 19(1), 1-10. https://doi.org/10.1002/csr.259

Eng, L. L., \& Mak, Y. T. (2003). Corporate governance and voluntary disclosure. Journal of Accounting and Publicy Policy, 22(4), 325-345. https://doi.org/10.1016/S0278-4254(03)00037-1

Fernandez-Feijoo, B., \& Romero, S. (2014). Effect of Stakeholders' Pressure on Transparency of Sustainability Reports within the GRI Framework. Journal of Business Ethics, 122(1), 53-63. https://doi.org/doi.org/10.1007/s10551$\underline{013-1748-5}$

Firer, S., \& Williams, S. M. (2005). Firm ownership structure and intellectual capital disclosures. South African Jpurnal of Accounting Research, 19(1), 1-18. https://doi.org/10.1080/10291954.2005.1143511 $\underline{6}$

Freeman, R. E., \& Mcvea, J. F. (2001). A Stakeholder Approach to Strategic Management, (January). https://doi.org/10.2139/ssrn.263511

Freeman, R. E., Wicks, A. C., \& Parmar, B. (2004). Revisited "Stakeholder Theory and "The Corporate Objective Revisited ," (September 2017). https://doi.org/10.1287/orsc. 1040.0066

Gamerschlag, R., Moller, K., \& Verbeeten, F. (2011). Determinants of voluntary CSR disclosure: empirical evidence from Germany. Review of Managerial Science, 5(2-3), 233-262. https://doi.org/10.1007/s11846-010-0052-3

Gao, F., Dong, Y., Ni, C., \& Fu, R. (2015). Determinants and Economic Consequences of Non-financial Disclosure Quality. European Accounting Review, 25(2), 287-317. https://doi.org/10.1080/09638180.2015.1013049

Garcia-Sanchez, I.-M., Cuadrado-Ballesteros, B., \& Sepulveda, C. (2014). Does media pressure moderate CSR disclosures by external directors ? Management Decision Journal, 52(6), 10141045. https://doi.org/10.1108/MD-09-2013-0446

Ghozali, I., \& Chariri, A. (2007). Teori Akuntansi (Edisi Keti). Semarang: Badan Penerbit Universitas Diponegoro.

GRI. (2011). Pedoman Pelaporan Keberlanjutan Versi 3.1.

GRI. (2013). Pedoman pelaporan keberlanjutan Versi 4.1.

Gunawan, J. (2015). Corporate social disclosures in Indonesia: stakeholders , influence and motivation. Social Responsibility Journal, 11(3), 535-552. https://doi.org/10.1108/SRJ-04-2014$\underline{0048}$

Guo, P., Chen, Y., Tan, X., Li, W., Zhang, J., Du, Y., \& Zhang, X. (2009). A Journey to Discover Values: A Study of Sustainability Reporting in China. SynTao. Retrieved from http://www.syntao.com

Guse, R. G., Almasan, A., Circa, C., \& Dumitru, M. (2016). The role of the stakeholders in the institutionalization of the CSR reporting in Romania. Accounting and Management Information System, 15(2), 304-340.

Haniffa, R. M., \& Cooke, T. E. (2005). The impact of culture and governance on corporate social reporting. Journal of Accounting and Publicy Policy, 24(5), 391-430. https://doi.org/10.1016/j.jaccpubpol.2005.06.001

Hartanto, A. H., \& Purwatiningsih. (2014). Pengaruh Stakeholders Power dan Karakteristik Perusahaan Terhadap Pengungkapan Sosial dan Lingkungan. Jurnal Fakultas Ekonomi Universitas Indonesia.

He, Z., Shen, W., Li, Q., Xu, S., Zhao, B., Long, R., \& Chen, H. (2017). Investigating external and internal pressures on corporate environmental behavior in papermaking enterprises of China. Journal of Cleaner Production, 172, 1193-1211. https://doi.org/10.1016/j.jclepro.2017.10.115

He, Z., Xu, S., Shen, W., Long, R., \& Chen, H. (2016). Factors that influence corporate environmental behavior: Empirical analysis based on panel data 
in China. Journal of Cleaner Production, 133, 531-543.

https://doi.org/10.1016/j.jclepro.2016.05.164

Huang, C., \& Kung, F. (2010). Drivers of Environmental Disclosure and Stakeholder Expectation: Evidence from Taiwan. Journal of Business Ethics, 96(3), 435-451. https://doi.org/10.1007/s10551-010-0476-3

Husen, Y. (2013). Kontradiksi Tanggungjawab Sosial dan Lingkungan PT Arun. Retrieved from https://www.kompasiana.com/yudi_husen/5529b b43f17e611920d623a6/kontradiksi-tanggungjawab-sosial-dan-lingkungan-pt-arun

Isenmann, R., \& Kim, K.-C. (2006). Interactive Sustainability Reporting. Developing Clear Target Group Tailoring and Stimulating Stakeholder Dialogue. In S. Schaltegge, M. Bennett, \& R. Burritt (Eds.), Sustainability Accounting and Repoting (Eco-Effici, Vol. 21, pp. 533-555). Springer. https://doi.org/10.1007/978-1-4020-4974-3_24

Jamali, D., \& Mirshak, R. (2007). Corporate Social Responsibility ( CSR ): Theory and Practice in a Developing Country Context. Journal of Business Ethics, 72(3), 243-262. https://doi.org/10.1007/s10551-006-9168-4

Jenawan, S., \& Juniarti. (2015). Pengaruh Pengungkapan Sustainability Reporting Terhadap Respon Investor. Business Accounting Review, $3(1)$.

Jensen, C. M., \& Meckling, H. W. (1976). THEORY OF THE FIRM : MANAGERIAL BEHAVIOR, AGENCY COSTS AND OWNERSHIP STRUCTURE. Jurnal of Financial Economics, 3(4), 305-360. https://doi.org/10.1016/0304$\underline{405 X(76) 90026-X}$

Kassinis, G., \& Vafeas, N. (2006). STAKEHOLDER PRESSURES AND ENVIRONMENTAL PERFORMANCE. Academy of Management Journal, $\quad 49(1)$, 145-159. https://doi.org/10.5465/AMJ.2006.20785799

Kaya, I. (2016). The Mandatory Social and Environmental Reporting: Evidence from. Procedia - Social and Behavioral Sciences, 229, 206-213. https://doi.org/10.1016/j.sbspro.2016.07.130

Keim, G. D. (1978). Managerial behavior and the social responsibility debate: Goal versus constraints. Academy of Management Journal, 21(1), 57-68. https://doi.org/10.5465/255662

Kumar, V., Gunasekaran, A., Singh, K., Papadopoulos, T., \& Dubey, R. (2015). Cross sector comparison of sustainability reports of Indian companies: A stakeholder perspective. Sustainable Production and Consumption, 4, 6271. https://doi.org/10.1016/j.spc.2015.08.005

Lamont, B. T. (2004). Redefining the Corporation: Stakeholder Management and Organizational Wealth by James E. Post, Lee E. Preston, Sybille Sachs. Administrative Science Quartely, 49(1), 145-147.

Laplume, A. O., Sonpar, K., \& Litz, R. A. (2008). Stakeholder Theory: Reviewing a. Journal of Management, $\quad 34(6), \quad$ 1152-1189. https://doi.org/10.1177/0149206308324322

Li, D., Lin, H., \& Yang, Y.-W. (2016). Does the stakeholders-corporate social responsibility (CSR) relationship exist in emerging countries? Evidence from China, 12(1), 147-166. https://doi.org/10.1108/SRJ-01-2015-0018

Liu, X., \& Anbumozhi, V. (2009). Determinant factors of corporate environmental information disclosure: an empirical study of Chinese listed companies. Journal of Cleaner Production, 17(6),

593-600. https://doi.org/10.1016/j.jclepro.2008.10.001

Lozano, R., \& Huisingh, D. (2011). Inter-linking issues and dimensions in sustainability reporting. Journal of Cleaner Production, 19(2-3), 99-107. https://doi.org/10.1016/j.jclepro.2010.01.004

Lu, Y., \& Abeysekera, I. (2014). Stakeholders ' power , corporate characteristics, and social and environmental disclosure: evidence from China. Journal of Cleaner Production, 64, 426-436. Retrieved from http://ro.uow.edu.au/buspapers/292

Maharani, S. N. (2015). SUSTAINABILITY REPORTING SEBAGAI MEDIA PERUSAHAAN DALAM MENGEMBANGKAN DAN. Jurnal Ekonomi 
Modernisasi,

10 ,

$11-22$.

https://doi.org/10.21067/jem.v10i1.770

Man, C. K. (2015). Phd Thesis: International Perspective: The Impact of Corporate Social International Perspectives: The impact of Corporate Sustainability Disclosure Decision, Disclosure Quality , Disclosure Quantity , Disclosure Index on Financial Analyst Following , . https://doi.org/10.2139/ssrn.2583165

Manetti, G. (2011). The Quality of Stakeholder Engagement in Sustainability Reporting: Empirical Evidence and Critical Points. Corporate Social Responsibility and Environmental Management Journal, 18, 110122. https://doi.org/10.1002/csr.255

Michelon, G., Pilonato, S., \& Ricceri, F. (2015). Critical Perspectives on Accounting CSR reporting practices and the quality of disclosure : An empirical analysis. Critical Perspectives on Accounting, 33, 59-78. https://doi.org/10.1016/j.cpa.2014.10.003

Mitchell, R. K., Agle, B. K., \& Wood, D. J. (1997). Toward a Theory of Stakeholder Identification and Salience: Defining the Principle of Who and What Really Counts. The Academy of Management Review, 22(4), 853-886. Retrieved from http://www.jstor.org/stable/259247

Ooghe, H., \& Langhe, T. De. (2002). The AngloAmerican versus the Continental European corporate governance model: empirical evidence of board composititon in Belgium. European Business Review, 14(6), 437-449. https://doi.org/10.1108/09555340210448794

Owen, D. L., Hunt, K., \& Swift, T. (2001). Questioning the Role of Stakeholder Engagement in Social and Ethical Accounting, Auditing and Reporting. Accounting Forum, 25(3), 264-282. https://doi.org/10.1111/1467-6303.00066

Perrini, F., Russo, A., \& Tencati, A. (2007). CSR Strategies of SMEs and Large Firms:Evidence from Italy. Journal of Business Ethics, 74, 285300 .

Retrieved from https://www.jstor.org/stable/25075465

Prado-Lorenzo, J.-M., Gallego-Alvarez, I., \& GraciaSanchez, I. M. (2009). Stakeholder engagement and corporate social responsibility reporting: the ownership structure effect. Corporate Social Responsibility and Environmental Management Journal, 16(2), 94-107. https://doi.org/10.1002/csr.189

Riatmoko, F. I. (2016). Evaluasi 10 Tahun Kasus Lapindo. Retrieved from https://regional.kompas.com/read/2016/04/26/15 050011/Evaluasi.10.Tahun.Kasus.Lapindo

Rizkika, A. D., \& Aryati, T. (2019). PENGARUH TEKANAN STAKEHOLDER DAN KINERJA KEUANGAN TERHADAP KUALITAS SUSTAINABILITY REPORT DENGAN KOMITE AUDIT SEBAGAI VARIABEL MODERASI. Jurnal Akuntansi Dan Keuangan Methodist, 2(2), 112-130.

Roberts, R. W. (1992). DETERMINANTS OF CORPORATE SOCIAL RESPONSIBILITY DISCLOSURE: AN APPLICATION OF STAKEHOLDER THEORY. Accounting,Organizations and Society, 17(6), 595-612. https://doi.org/10.1016/03613682(92)90015-K

Rudyanto, A., \& Siregar, S. V. (2018). The effect of stakeholder pressure and corporate governance on the quality of sustainability report International Journal of Ethics and Systems Article information: Internasional Journal of Ethics and Systems, 34(2), 233-249. https://doi.org/10.1108/IJOES-05-2017-0071

Rusdianto, U. (2013). CSR Communication A Framework for PR Practitioners. Graha Ilmu.

Said, R., Zainuddin, Y. H., \& Haron, H. (2009). The relationship between corporate social responsibility disclosure and corporate governance characteristics in Malaysian public listed companies. Social Responsibility Journal, $5(2)$, 212-226. https://doi.org/10.1108/17471110910964496

Saka, C., \& Noda, A. (2013). THE EFFECTS OF STAKEHOLDERS ON CSR DISCLOSURE: EVIDENCE FROM JAPAN. Proceedings of the Seventh Asia Pacific Interdisciplinary Research in Accounting Conference. https://doi.org/10.2139/ssrn.2239469 
Sekaran, U., \& Bougie, R. (2017). Metode Penelitian untuk Bisnis (6th ed.). Jakarta: Salemba Empat.

Şener, İ., Varoğlu, A., \& Anıl, A. (2016). Sustainability Reports Disclosures: Who are the Most Salient Stakeholders ?, 235, 84-92. https://doi.org/10.1016/j.sbspro.2016.11.028

Simbolon, J., \& Memed, S. (2016). Pengaruh Pengungkapan Sustainability Report Terhadap Kinerja Keuangan Perusahaan ( Studi Empiris pada Perusahaan Tambang dan Infrastruktur Subsektor Energi yang Terdaftar di BEI Tahun 2010-2014 ). Simposium Nasional Akuntansi XIX, Lampung, 1-30.

Siregar, S. V., \& Bachtiar, Y. (2010). Corporate Social Reporting: Empirical Evidence from Indonesia Stock Exchange. Internasional Journal of Islamic and Middle Eastern Finance and Management, 3(3), 241-252.

Solikhah, B., \& Winarsih, A. M. (2016). PENGARUH LIPUTAN MEDIA, KEPEKAAN INDUSTRI, DAN STRUKTUR TATA KELOLA PERUSAHAAN TERHADAP KUALITAS PENGUNGKAPAN LINGKUNGAN. Jurnal Akuntansi Dan Keuangan Indonesia, 13(1), 122.

Suastha, R. D. (2016). Riset Temukan Kualitas CSR Perusahaan Indonesia Rendah. Retrieved December 20, 2019, from https://www.cnnindonesia.com/nasional/2016072 1074144-20-146030/riset-temukan-kualitas-csrperusahaan-indonesia-rendah?

Suchman, M. C. (1995). Managing Legitimacy: Strategic and Institutional Approaches. The Academy of Management, 20(3), 571-610. https://doi.org/10.2307/258788

Sun, L., \& Yu, T. R. (2015). The impact of corporate social responsibility on employee performance and cost. Review of Accounting and Finance, 14(3), 262-284. https://doi.org/10.1108/RAF-032014-0025

Sweeney, L., \& Coughlan, J. (2011). Do Different Iindustries Report Corporate Social Responsibility Differently?: An Investigation Through the Lens of Stakeholder Theory. Journal of Marketing Communications, 14(2),
113-124.

https://doi.org/10.1080/13527260701856657

Tang, Z., \& Tang, J. (2012). Stakeholder - firm power difference, stakeholders ' CSR orientation, and SMEs environmental performance in China. Journal of Business Venturing, 27(4), 436-455. https://doi.org/10.1016/j.jbusvent.2011.11.007

Tarigan, J., \& Semuel, H. (2014). Pengungkapan Sustainability Report dan Kinerja Keuangan. Jurnal Akuntansi Dan Keuangan, 16(2), 88-101. https://doi.org/10.9744/jak.16.2.88-101

Thomsen, S., \& Pedersen, T. (2000). Ownership Structure and Economic Performance in the Largest European companies 1. Strategic Management Journal, 21(6), 689-705. https://doi.org/10.1002/(SICI)10970266(200006)21:6<689::AIDSMJ115>3.0.CO;2-Y

Toms, J. S. (2002). Firm Resources , Quality Signals and the Determinants of Corporate Environmental Reputation: Some UK Evidence ENVIRONMENTAL REPUTATION: SOME UK EVIDENCE. British Accounting Review, 34(3), 257-282. https://doi.org/10.1006/bare.2002.0211

Turban, D. B., \& Greening, D. W. (1997). CORPORATE SOCIAL PERFORMANCE AND ORGANIZATIONAL ATTRACTIVENESS TO PROSPECTIVE EMPLOYEES. Academy of Management Journal, 40(3), 658-672. https://doi.org/10.2307/257057

Ullmann, A. A. (1985). Data in Search of a Theory: A Critical Examination of the Relationships Among Social Performance, Social Disclosure, and Economic Performance of U . S . Firms. The Academy of Management, 10(3), 540-557. https://doi.org/10.5465/AMR.1985.4278989

Villiers, C. De, \& Alexander, D. (2014). The Institutionalisation of Corporate Social Responsibility Reporting. The British Accounting Review, 46 (2), 198-212.

Wahyuni, E. T. (2015). Masyarakat Ekonomi Asean Segera Datang: Tuntutan Pelaporan Keuangan Semakin Kompleks: Sustainability report. Institusi Akuntansi Publik Indonesia, 42-44. 
Retrieved from http://etwaccountant.com/tag/sustainability-report/

Wang, J., Tian, G., Fan, W., \& Luo, D. (2017). The Effect Of Mandatory Regulation On Corporate Social Responsibility Reporting Quality: Evidence From China. The Journal of Applied Business Research, 33(1), 67-86. https://doi.org/10.19030/jabr.v33i1.9861

Weaver, G. R., Treviño, L. K., \& Cochran, P. L. (1999). INTEGRATED AND DECOUPLED CORPORATE SOCIAL PERFORMANCE : MANAGEMENT COMMITMENTS, EXTERNAL PRESSURES , AND CORPORATE ETHICS PRACTICES. The Academy of Management Journal, 42(5), 539552. https://doi.org/10.2307/256975 